\title{
Activities of amphotericin B, fluconazole and voriconazole against Candida bloodstream isolates determined by broth microdilution and disk diffusion methods
}

\author{
Amfoterisin B, flukonazol ve vorikonazollünün kan kültüirlerinden izole \\ edilen Candida türlerine karșı antifungal aktivitesinin mikrodilüsyon \\ ve disk diffüzyon yöntemleri ile belirlenmesi
}

\author{
Nimet YiĞiT ${ }^{1}, \quad$ Esin AKTAȘ²
}

\section{ÖZET}

Amaç: Candida türlerinin neden olduğu invaziv fungal enfeksiyonlar önemli ölçüde artmıștır. Kandidemiler sadece mortalite ile ilișkili olmayıp, aynı zamanda hastanede kalış süresinin uzamasına ve tıbbi bakım maliyetinin artmasına da sebep olmaktadır. Candida albicans ve non-albicans Candida türlerinin neden olduğu kandidemilerde, hastaların klinik bulgularının aynı olmasına rağmen bu türlerin antifungal ilaçlara duyarlılıkları da farklıdır. Bu çalıșmada; Candida kan izolatlarının antifungal duyarlılık verilerini sunmaktadır.

Yöntem: 35 Candida albicans, 25 Candida tropicalis, 15 Candida parapsilosis, 8 Candida glabrata, 4 Candida krusei ve 3 Candida kefyr olmak üzere toplam 90 Candida izolatı incelendi. Bu türlerin amfoterisin $\mathrm{B}$, flukonazol ve vorikonazole karșı antifungal duyarlılıkları \%2 glukozla zenginleștirilmiş RPMI 1640 agar besiyeri kullanılarak mikrodilüsyon yöntemi (CLSI M27-A3) ve 0,5 $\mu \mathrm{g} / \mathrm{mL}$ metilen mavisi ve $\% 2$ glukozla zenginleștirilmiș MuellerHinton agar besiyeri kullanılarak disk diffüzyon (CLSI M44-A2) yöntemi ile belirlendi.

Bulgular: Candida izolatları mikrodilüsyon yöntemi ile $\% 87,7$ oranında, disk diffüzyon yöntemi ile $\% 82,2$ oranında flukonazole duyarlı bulundu.

\section{ABSTRACT}

Objective: Invasive fungal infections caused by Candida species have increased significantly. Candidemia is not only associated with a mortality, but also extends the duration of hospital stay and increases the cost for medical care. Although, the clinical presentations of the patients with candidemia caused by Candida albicans and non-albicans Candida species are indistinguishable, the susceptibilities to antifungal agents of these species are different. This study presents data on antifungal susceptibility profiles of Candida bloodstream isolates.

Method: We tested a total of 90 strains, including 35 strains of Candida albicans, 25 strains of Candida tropicalis, 15 strains of Candida parapsilosis, 8 strains of Candida glabrata, 4 strains of Candida krusei and 3 strains of Candida kefyr. Susceptibility to amphotericin B, fluconazole and voriconazole was determined by Clinical Laboratory Standards Institute broth microdilution method (CLSI M27-A3) using RPMI 1640 as test medium supplemented with $2 \%$ glucose and disk diffusion methods were performed according to CLSI M44-A2 using methylene blue $(0.5 \mu \mathrm{g} / \mathrm{mL})$ and glucose $(2 \%)$ enriched Mueller-Hinton agar.

Results: In this study, $87.7 \%, 82.2 \%$ of Candida isolates were susceptible to fluconazole with the broth

\footnotetext{
${ }^{1}$ Atatürk Üniversitesi, Sağlık Hizmetleri Meslek Yüksekokulu, ERZURUM

${ }^{2}$ Atatürk Üniversitesi, Tıp Fakültesi, Mikrobiyoloji Ve Klinik Mikrobiyoloji Ana Bilim Dalı, ERZURUM
}

İletişim/Corresponding Author: Nimet Yí̆̌iT

Atatürk Üniversitesi, Sağlık Hizmetleri Meslek Yüksekokulu, ERZURUM

Tel : $+904422315853-5865$

E-posta/E-mail : nimyigit@hotmail.com

Geliş Tarihi / Received : 14.02.2014

Kabul Tarihi / Accepted : 22.04.2014

DOI ID : 10.5505/TurkHijyen.2014.05658

Yiğit N, Aktaș E. Activities of amphotericin B, fluconazole and voriconazole against Candida bloodstream isolates determined by broth microdilution and disk diffusion methods. Turk Hij Den Biyol Derg, 2014; 71(3): 131-40. 
Mikrodilüsyon yöntemi ile bu izolatların \%6,6'sı $(\% 8,5$ C. albicans, $\% 4,0$ C. tropicalis ve $\% 25,0$ C. glabrata) flukonazole karșı doza bağlı duyarlı, \%5,5 ise dirençli olarak belirlendi. Dirençli suşların dördü C. krusei (\%100), biri ise C. albicans $(\% 2,8)$ idi. Disk diffüzyon yöntemi ile Candida sușlarının \%12,2'si doza bağlı duyarlı (\%17,1 C. albicans, \%12,0 C. tropicalis and $\% 25,0$ C. glabrata) olarak, $\% 5,5^{\prime} \mathrm{i}$ [bir izolat C. albicans $(\% 2,8)$, dört izolat C. krusei (\%100)] ise flukonazole dirençli olarak belirlendi. Bütün sușlar amfoterisin B ve vorikonazole duyarlı olarak bulundu.

Sonuç: Amfoterisin B ve vorikonazollün Candida izolatlarına karșı in-vitro aktivitesinin yüksek olduğu belirlendi. Antifungal ilaçlara direnç artmaktadır ki bundan dolayı fungal patojenlerin duyarlılık profillerini değerlendirmek giderek önem kazanmaktadır.

Anahtar Kelimeler: Antifungal duyarlılık, flukonazol, kan izolatları microdilution method and the disk diffusion method respectively, based on CLSI breakpoints. A further 6.6\% were classified as susceptible-dose-dependent $(8.5 \%$ C. albicans, $4.0 \%$ C. tropicalis and $25.0 \%$ C. glabrata) and fluconazole resistance was detected in $5.5 \%$ of all isolates by microdilution method. Four isolates of these strains were $C$. krusei $(100 \%)$ and one strain was C. albicans (2.8\%). $12.2 \%$ of Candida spp. were classified as susceptible-dose-dependent $(17.1 \%$ C. albicans, $12.0 \%$ C. tropicalis, and $25.0 \%$ C. glabrata) and fluconazole resistance was detected in $5.5 \%$ of all isolates. Four isolates of these strains were C. krusei $(100 \%)$ and one strain was $C$. albicans (2.8\%) by disk diffusion method. All isolates were susceptible to amphotericin B and voriconazole using by two methods.

Conclusion: Voriconazole and amphotericin B were active in-vitro against yeasts. As antifungal drug resistance may become more frequent, it is increasingly important to evaluate current antifungal susceptibility profiles of fungal pathogens.

Key Words: Antifungal susceptibility, fluconazole, bloodstream isolates

\section{INTRODUCTION}

A progressive increase in the frequency of candidemia has been observed, particularly among patients receiving antibiotics, immunosuppressive therapy, or parenteral nutrition, as well as among patients exposed to invasive medical procedures such as intravascular catheter, hemodialysis and abdominal surgery (1-3).

Candidemia have been associated with significant mortality, especially among critically ill patients. The attributable mortality of candidemia has been estimated at 25-38\%. In addition, an increase of 30 days in the length of hospital stay among patients surviving these infections has been demonstrated. The economic impact of these infections is also important (3-6).

Although Candida albicans is still considered the most frequently isolated species of candidemic patients, the emergence of non-albicans Candida species is clearly a concern. The resistance of non- albicans Candida isolates to currently available antifungal drugs represents a major challenge for future empirical therapeutic and prophylactic strategies. Therefore, species directed therapy should be administered for fungemia according to the species identified and its antifungal susceptibility pattern $(1,3)$.

Candida species have various degrees of susceptibility to frequently used antifungal drugs. For instance, Candida lusitaniae is relatively resistant to amphotericin B, C. krusei is intrinsically resistant to fluconazole, C. glabrata is less susceptible or has a higher MICs to it than other Candida species. This phenomenon illustrates the importance of identification and surveillance of Candida species in the clinical settings (7).

Large-scale surveillance for bacteremia and fungemia has been conducted world-wide by various organizations, including the Centers for Disease 
Control and Prevention (CDC) and the National Epidemiology of Mycoses Survey (NEMIS). These surveys provide evidence that the prevalence of azole-resistant fungi is increasing (8).

The antifungal susceptibility testing of pathogenic fungi can manage the selection of adequate therapy and also provide an estimate of antifungal efficacy. Monitoring of drug resistance development can predict therapeutic outcome and therapeutic potential of untested compounds (9).

With the increasing incidence of yeast infections and the emergence of resistant strains to antifungal drugs, it has become essential for diagnostic laboratories not only to isolate and identify Candida species but also to perform routine susceptibility testing (10).

The Clinical and Laboratory Standards Institute (CLSI) provides recommendations for broth microdilution antifungal susceptibility testing of yeasts, a method that is reproducible and presents good clinical correlation. However, this method is labor-intensive and unsuitable for most routine diagnostic laboratories (10).

Correlation between results generated by the CLSI microdilution standard reference method and a disk diffusion assay using Mueller-Hinton agar supplemented with $2 \%$ glucose and $0.5 \mu \mathrm{g} /$ $\mathrm{mL}$ methylene blue agar has been documented by several investigators. Breakpoints for susceptibility of fluconazole and voriconazole are now available for disk diffusion assay which have the advantages of being easy to perform, accurate, inexpensive and suitable for routine laboratories (10).

The purpose of this study was to test Candida species obtained from blood culture against amphotericin B, fluconazole and voriconazole by using the broth microdilution and disk diffusion methods.

\section{MATERIALS and METHODS}

\section{Candida Isolation and Identification}

This study was designed in Mycology Laboratory, Microbiology and Clinical Microbiology Department of Medical Faculty between 2011 to 2013 years. A total of 90 yeast isolates were tested. All the organisms were clinical blood isolates obtained from patients hospitalized. The isolates were identified by standard conventional methods. For species typing of the isolates, germ tube and chlamydospore production tests were performed. The carbohydrate assimilation patterns of all isolates were studied using the API 20 C AUX system (Biomerieux) according to the manufacturer's procedure. The yeasts were maintained on Sabouraud glucose agar slants, stored at $4{ }^{\circ} \mathrm{C}$, until used in the study. Prior to testing, each strain was subcultured on Sabouraud agar for $24 \mathrm{~h}$ at $35{ }^{\circ} \mathrm{C}$ to ensure viability. C. krusei ATCC 6258 and $C$. parapsilosis ATCC 22019 were tested each time a set of clinical isolates was evaluated (11).

\section{Antifungal Susceptibility Test}

Microdilution Method: Reference antifungal susceptibility testing of Candida spp. was performed using the microdilution method described in CLSI M27-A3 (12). Reference powders of amphotericin B (Sigma), flukonazole (Pfizer) and voriconazole (Pfizer) were used. Stock solutions were prepared with a concentration 10 fold the final concentration and diluted with RPMI 1640 (Sigma), with L-glutamine, without bicarbonate, supplemented with $2 \%$ dextrose and buffered to $\mathrm{pH} 7.0$ with 0.165 $\mathrm{N}$-morpholinopropanesulfonic acid (MOPS) to obtain twice the final concentration.

Disk Diffusion Method: Disk diffusion testing of amphotericin B, flukonazole and voriconazole was performed as described by CLSI document M44-A2 (13). In our study; disks containing; $25 \mu \mathrm{g}$ of fluconazole (Becton Dickinson, Sparks, MD), 1 $\mu \mathrm{g}$ of voriconazole (Becton Dickinson, Sparks, MD) 
and $20 \mu \mathrm{g}$ of amphotericin B (MAST Diagnostics) were used. Initially, a yeast inoculums suspension adjusted to match a 0.5 McFarland density standard was prepared. A sterile cotton swab moistened with inoculums suspension was used to apply each organism to be tested on a $90 \mathrm{~mm}$ diameter plate containing Mueller-Hinton agar supplemented with $2 \%$ glucose and $0.5 \mu \mathrm{g} / \mathrm{mL}$ methylene blue. The plates were allowed to dry for 5-15 min before the disks to be placed in the agar. The plates were incubated for $18-24 \mathrm{~h}$ at $35-37^{\circ} \mathrm{C}$, and the slowly growing isolates could be read after $24 \mathrm{~h}$ incubation. All inhibition zone diameters generated by disk diffusion tests were read and recorded $(10,14,15)$. The interpretive criteria for the fluconazole disk test were $\mathrm{dz} \geq 19 \mathrm{~mm}: \mathrm{S}, 15<\mathrm{dz}<18 \mathrm{~mm}$ : S-DD, $\mathrm{dz} \leq 14 \mathrm{~mm}: \mathrm{R}$, for voriconazole disk test were $\mathrm{dz} \geq$ $17 \mathrm{~mm}$ : S, $14<\mathrm{dz}<16 \mathrm{~mm}$ : S-DD, dz $\leq 13 \mathrm{~mm}: \mathrm{R}$, for amphotericin $B$ disk test $d z \leq 10 \mathrm{~mm}: \mathrm{R}(13,16)$.

\section{RESULTS}

A total of 90 Candida spp. were isolated from clinical blood samples obtained from patients hospitalized. The most species isolated was $C$. albicans followed by C. tropicalis, C. parapsilosis, C. glabrata, C. krusei and C. kefyr (Table 1).

Table 1. Species distribution of Candida isolated from blood cultures

\begin{tabular}{lcc}
\hline Species & $\begin{array}{c}\text { Number of } \\
\text { isolates }\end{array}$ & \% of isolates \\
\hline C. albicans & 35 & $39.0 \%$ \\
C. tropicalis & 25 & $28.0 \%$ \\
C. parapsilosis & 15 & $16.5 \%$ \\
C. glabrata & 8 & $8.8 \%$ \\
C. krusei & 4 & $4.4 \%$ \\
C. kefyr & 3 & $3.3 \%$ \\
\hline Total & 90 & 100
\end{tabular}

Table 2. In vitro susceptibilities of Candida bloodstream isolates to fluconazole, voriconazole and amphotericin B by using microdilution method

\begin{tabular}{|c|c|c|c|c|}
\hline Species and Number & Antifungal agent & $\begin{array}{l}\text { MIC range } \\
(\mu \mathrm{g} / \mathrm{mL})\end{array}$ & $\begin{array}{c}M^{M^{2} C_{50}} \\
(\mu \mathrm{g} / \mathrm{mL})\end{array}$ & $\begin{array}{c}\mathrm{MIC}_{90} \\
(\mu \mathrm{g} / \mathrm{mL})\end{array}$ \\
\hline \multirow[t]{3}{*}{ C. albicans -35} & Fluconazole & $0.125-64$ & 0.5 & 16 \\
\hline & Voriconazole & $0.125-1$ & 0.25 & 0.5 \\
\hline & Amphotericin B & $0.03-0.5$ & 0.125 & 0.25 \\
\hline \multirow[t]{3}{*}{ C. tropicalis -25} & Fluconazole & $0.125-32$ & 0.5 & 2 \\
\hline & Voriconazole & $0.125-1$ & 0.25 & 0.5 \\
\hline & Amphotericin B & $0.03-0.5$ & 0.125 & 0.25 \\
\hline \multirow[t]{3}{*}{ C. parapsilosis -15} & Fluconazole & $0.125-4$ & 0.25 & 0.5 \\
\hline & Voriconazole & $0.125-0.5$ & 0.125 & 0.5 \\
\hline & Amphotericin B & $0.03-0.5$ & 0.06 & 0.25 \\
\hline \multirow[t]{3}{*}{ C. glabrata -8} & Fluconazole & $0.125-32$ & 0.5 & 1 \\
\hline & Voriconazole & $0.125-1$ & 0.25 & 0.25 \\
\hline & Amphotericin B & $0.06-1$ & 0.5 & 1 \\
\hline \multirow[t]{3}{*}{ C. krusei -4} & Fluconazole & 64 & 64 & 64 \\
\hline & Voriconazole & $0.25-1$ & 0.25 & 0.5 \\
\hline & Amphotericin B & $0.125-1$ & 0.25 & 0.5 \\
\hline \multirow[t]{3}{*}{ C. kefyr -3} & Fluconazole & $0.125-0.25$ & 0.25 & 0.25 \\
\hline & Voriconazole & $0.125-0.25$ & 0.125 & 0.25 \\
\hline & Amphotericin B & $0.03-0.125$ & 0.06 & 0.125 \\
\hline
\end{tabular}


Table 2 shows MIC, MIC $_{50}$ and MIC $_{90}$ values exhibited by the three antifungal drugs tested against Candida spp. strains. Candida isolates were all susceptible to amphotericin B and voriconazole. Six Candida strains were susceptibility dose dependent (DD) to fluconazole $(16-32 \mu \mathrm{g} / \mathrm{mL})$. Three of these strains were $C$. albicans, one $C$. tropicalis and two $C$. glabrata. Five strains (four $C$. krusei and one $C$. albicans) were resistant to fluconazole ( $\geq 64 \mu \mathrm{g} / \mathrm{mL}$ ).

In-vitro antifungal activity of fluconazole, voriconazole and amphotericin B against Candida species by using disk diffusion method were summarized in Table 3. Five strains (four C. krusei and one $C$. albicans) were resistant to fluconazole (dz $\leq 14 \mathrm{~mm}: \mathrm{R}$ ). Eleven Candida isolates (six C. albicans, three $C$. tropicalis and two C. glabrata) were susceptibility dose dependent (DD) to fluconazole $(15<\mathrm{dz}<18 \mathrm{~mm}$ : S-DD) by disk diffusion method. Five fluconazole-sensitive Candida strains that determined by the microdilution method was found to be dose-dependent susceptibility in the disk diffusion method.

\section{DISCUSSION}

The importance of Candida spp. as etiologic agents of bloodstream infections in hospitalized patients is well established. C. albicans isolates usually are susceptible to commonly used azoles such as itraconazole or fluconazole. Nevertheless within the past decade, the proportion of infections caused by non-albicans Candida species has increased exponentially. Nearly one half of the cases of hematogenous candidiasis are now reported to be the result of Candida species other than albicans. The reasons for the shift are unclear and probably multifactorial. Among others, routine prophylactic use of antifungal agents such as fluconazole in immunocompromised patients can be implicated in the shift of species with known reduced susceptibility such as $C$. glabrata or $C$. krusei, which is intrinsically resistant to fluconazole $(4,16)$. Several of these species exhibit resistance to traditional triazole antifungals like fluconazole, and may also demonstrate cross-resistance to newer triazoles. This makes it imperative to perform both

Table 3. In vitro antifungal activity of fluconazole, voriconazole and amphotericin B against Candida bloodstream isolates by using disk diffusion method

\begin{tabular}{|c|c|c|c|c|c|c|c|c|c|c|c|}
\hline \multirow{2}{*}{$\begin{array}{l}\text { Candida } \\
\text { species }\end{array}$} & \multirow{2}{*}{$\begin{array}{l}\text { Number of } \\
\text { isolates }\end{array}$} & \multirow{2}{*}{$\begin{array}{c}\% \text { of } \\
\text { isolates }\end{array}$} & \multicolumn{3}{|c|}{ Fluconazole } & \multicolumn{3}{|c|}{ Voriconazole } & \multicolumn{3}{|c|}{ Amphotericin B } \\
\hline & & & $\mathrm{S}$ & SDD & $\mathbf{R}$ & $S$ & SDD & $\mathbf{R}$ & $S$ & SDD & $\mathbf{R}$ \\
\hline C. albicans & 35 & 39.0 & $\begin{array}{c}28 \\
80.0 \%\end{array}$ & $\begin{array}{c}6 \\
17.1 \%\end{array}$ & $\begin{array}{c}1 \\
2.8 \%\end{array}$ & $\begin{array}{c}35 \\
100 \%\end{array}$ & - & - & $\begin{array}{c}35 \\
100 \%\end{array}$ & - & - \\
\hline C. tropicalis & 25 & 28.0 & $\begin{array}{c}22 \\
88.0 \%\end{array}$ & $\begin{array}{c}3 \\
12.0 \%\end{array}$ & - & $\begin{array}{c}25 \\
100 \%\end{array}$ & - & - & $\begin{array}{c}25 \\
100 \%\end{array}$ & - & - \\
\hline C. parapsilosis & 15 & 16.5 & $\begin{array}{c}15 \\
100 \%\end{array}$ & - & - & $\begin{array}{c}15 \\
100 \%\end{array}$ & - & - & $\begin{array}{c}15 \\
100 \%\end{array}$ & - & - \\
\hline C. glabrata & 8 & 8.8 & $\begin{array}{c}6 \\
75.0 \%\end{array}$ & $\begin{array}{c}2 \\
25.0 \%\end{array}$ & - & $\begin{array}{c}8 \\
100 \%\end{array}$ & - & - & $\begin{array}{c}8 \\
100 \%\end{array}$ & - & - \\
\hline C. krusei & 4 & 4.4 & - & - & $\begin{array}{c}4 \\
100 \%\end{array}$ & $\begin{array}{c}4 \\
100 \%\end{array}$ & - & - & $\begin{array}{c}4 \\
100 \%\end{array}$ & - & - \\
\hline C. kefyr & 3 & 3.3 & $\begin{array}{c}3 \\
100 \%\end{array}$ & - & - & $\begin{array}{c}3 \\
100 \%\end{array}$ & - & - & $\begin{array}{c}3 \\
100 \%\end{array}$ & - & - \\
\hline Total & 90 & 100 & $\begin{array}{c}74 \\
82.2 \%\end{array}$ & $\begin{array}{c}11 \\
12.2 \%\end{array}$ & $\begin{array}{c}5 \\
5.5 \%\end{array}$ & $\begin{array}{c}90 \\
100 \%\end{array}$ & - & - & $\begin{array}{c}90 \\
100 \%\end{array}$ & - & - \\
\hline
\end{tabular}


speciation and antifungal susceptibility testing of all yeast fungi isolated from bloodstream or otherwise (6).

In this study, we isolated 90 strains from clinical blood samples with higher rate of $C$. albicans (39.0\%), followed by C. tropicalis $(28.0 \%)$, and C. parapsilosis (16.5\%). The similar rates have been presented in other studies $(1,2,6,18-23)$. Surveillance studies such as NEMIS, Surveillance and Control of Pathogens of Epidemiologic Importance (SCOPE), and a SENTRY Antimicrobial Surveillance Program revealed that $C$. albicans accounted for $54 \%, 52 \%$, and $53 \%$ of Candida isolates, respectively $(8,16,24)$.

Currently, in vitro susceptibility tests can allow very important guidelines for candidiasis treatment, but the standard susceptibility test (CLSI M27-A3) is not always readily available in regular laboratories and is very time consuming, in opposition to the other more simple techniques such as E-test and disk diffusion test. The major feature of these agar based tests is that they can allow a quick answer concerning Candida resistance to antifungal agents, preventing unnecessary patients drug abuse $(9,10$, 14, 21, 25).

Fluconazole is a useful antimycotic, and is commonly used for treatment of candidemia. Strains of C. albicans primarily resistant to fluconazole have been identified in clinical blood isolates by several authors, varying in frequency between $0 \%$ and $38 \%(26-29)$.

In our present study, with the broth microdilution method, $87.7 \%$ of Candida isolates were susceptible to fluconazole based on CLSI breakpoints, and a further $6.6 \%$ were classified as susceptible-dosedependent $(8.5 \%$ C. albicans, $4.1 \%$ C. tropicalis and $25 \%$ C. glabrata). Fluconazole resistance was detected in $5.5 \%$ of all isolates. Four isolates of these strains were C. krusei (100\%) and one strain was C. albicans $(2.8 \%)$.

In this study, with the disk diffusion method, 82.2\% of Candida isolates were susceptible to fluconazole based on CLSI breakpoints, and a further $12.2 \%$ were classified as susceptible-dose-dependent (17.1\% C. albicans, $12.0 \%$ C. tropicalis and 25\% C. glabrata). Fluconazole resistance was detected in $5.5 \%$ of all isolates. Four isolates of these strains were C. krusei (100\%) and one strain was C. albicans $(2.8 \%)$.

Clinical backgrounds revealed that $C$. krusei infection was seen almost exclusively as a complication of hematological malignancy. All patients who had $C$. krusei infections had been treated orally with fluconazole for the prevention of intestinal mycoses. Consequently, fluconazoleresistant $C$. krusei remained in the intestine, from which the organisms are likely to have become translocated into the circulation. Thus, it is seems that the presence of antimycotic resistant strains of fungi is always conceivable in patients with hematological malignancies (8).

In our study, $100 \%$ of C. krusei strains were classified as in vitro resistant to fluconazole. The resistance rates to fluconazole were higher than $80 \%$ usually reported by most authors in other studies. Regardless of the results obtained with in vitro studies, C. krusei strains should be considered as inherently resistant to fluconazole $(4,21,23,30$, 31).

C. glabrata, a species that easily acquires azoles drug resistance, is represented in European surveillance data of the 1990s at proportions in the range $9 \%-16 \%$, depending on the geographic location (30). It has been reported that continuous exposure to azoles seems to have a major impact on developing resistance to fluconazole in Candida 
species, especially for C. glabrata (7). In this study, C. glabrata accounted $8.8 \%$ of bloodstream isolates and a further $25 \%$ were classified as susceptibledose-dependent to fluconazole by two methods.

Blood stream infection due to $C$. kefyr is uncommon, but there have been some reports in immunocompromised patients and resistance to antifungals in the literature $(9,18,23)$. In the present study, 3.3\% of Candida isolates were C. kefyr of which were sensitive fluconazole, voriconazole and amphotericin B.

In our study, all C. parapsilosis isolates were susceptible to three antifungals and one $C$. tropicalis (4.1\%) were classified as susceptible-dose-dependent to fluconazole by microdilution method. Three $C$. tropicalis isolates $(12.0 \%)$ were susceptible-dosedependent to fluconazole by disk diffusion method. The increasing rate of reduced susceptibility to fluconazole in $C$. tropicalis has considerable clinical importance, because this species is one of the most frequently isolated non albicans Candida species. Furthermore, $C$. tropicalis develops drugs resistance in presence of fluconazole much more rapidly than C. albicans (7).
Amphotericin B was the first systemic antifungal agent for the treatment of invasive fungal infections and has been the drug of choice; however, due to nephrotoxicity in up to $80 \%$ of the patients, use of amphotericin B has been limited. Amphotericin B is effective against Candida spp. that are resistant to other antifungal agents (9). In our study, all isolates were susceptible to amphotericin B. Voriconazole was the triazole with the high in vitro antifungal activity against all Candida strains by use two methods and all isolates were susceptible to voriconazole.

In conclusion, the successful treatment of candidemia depends on the early identification of the species and sensitivity patterns to antifungal agents. The high growing rate of non albicans Candida resistant to azoles confirms the importance of monitoring changes in the distribution of pathogenic Candida species. The sensitivity pattern of Candida species as revealed in this study shows that amphotericin $B$ and voriconazole were active antifungal against Candida spp. 


\section{REFERENCES}

1. Godoy P, Tiraboschi IN, Severo LC, Bustamante B, Calvo B, de Almeda LP, et al. Species distribution and antifungal susceptibility profile of Candida spp. bloodstream isolates from Latin America Hospitals. Mem Inst Oswaldo Cruz, 2003; 98 (3): 401-5.

2. da Matta DA, de Almeida LP, Machado AM, Azevedo AC, Kusano EJ, Travassos NF, et al. Antifungal susceptibility of 1000 Candida bloodstream isolates to 5 antifungal drugs: results of a multicenter study conducted in Sao Paulo, Brazil, 1995-2003. Diagn Microbiol Infect Dis, 2007; 57 (4): 399-404.

3. Al-Jasser AM, Elkhizzi NA. Distribution of Candida species among bloodstream isolates. Saudi Med J, 2004; 25 (5): 566-9.

4. Peman J, Canton E, Gobernado M. Epidemiology and antifungal susceptibility of Candida species isolated from blood: results of a 2-year multicenter study in Spain. Eur J Clin Microbiol Infect Dis, 2005; 24: 23-30.

5. Cheng MF, Yang YL, Yao TJ, Lin JY, Liu JS, Tang $\mathrm{RB}$, et al. Risk factors for fatal candidemia caused by Candida albicans and non-albicans Candida species. BMC Infect Dis, 2005; 5: 22.

6. Oberoi JK, Wattal C, Goel N, Raveendran R, Datta $\mathrm{S}$, Prasad K. Non-albicans Candida species in bloodstream infections in a tertiary care hospital at New Delhi, India. Indian J Med Res, 2012; 136 (6): 997-1003.

7. Yang $\mathrm{YL}$, Wang $\mathrm{AH}$, Wang CW, Cheng WT, Li SY, Lo HJ, et al. Susceptibilities to amphotericin B and fluconazole of Candida species in Taiwan surveillance of antimicrobial resistance of yeasts 2006. Diagn Microbiol Infect Dis, 2008; 61 (2): 175-80.
8. Nakamura T, Takahashi H. Epidemiological study of Candida infections in blood: susceptibilities of Candida spp. to antifungal agents, and clinical features associated with the candidemia. J Infect Chemother, 2006; 12 (3): 132-8.

9. Badiee P, Alborzi A. Susceptibility of clinical Candida species isolates to antifungal agents by E-test, Southern Iran: A five year study. Iran J Microbiol, 2011; 3 (4): 183-8.

10. Azevedo AC, Bizerra FC, de Matta DA, de Almeida LP, Rosas R, Colombo AL. In vitro susceptibility of a large collection of Candida strains against fluconazole and voriconazole by using the CLSI disk diffusion assay. Mycopathologia, 2011; 171 (6): 411-6.

11. Moracea G, Polonelli L. Voriconazole activity against clinical yeast isolates: a multicentre Italian study. Int J Antimicrob Ag, 2005; 26: 247-53.

12. Anonmyous. References method for broth dilution antifungal susceptibility testing of yeasts: USA: Clinical and Laboratory Standards Institute, Wayne, PA. Approved Standard, 3rd ed., CLSI document M27-A3, 2008.

13. Anonmyous. Method for antifungal disk diffusion susceptibility testing of yeasts: USA: Clinical and Laboratory Standards Institute, Wayne, PA. Approved Guideline-2nd ed., M44-A2, 2009.

14. Negri $M$, Henriques $M$, Svidzinski TIE, Paula $C R$, Oliveira R. Correlation between E-test disk diffusion, and microdilution methods for antifungal susceptibility testing of Candida species from infection and colonization. J Clin Lab Anal, 2009; 23: $324-30$.

15. Mandras N, Tullio V, Allizond V, Scalas D, Branche G, Roana J, et al. In vitro activities of fluconazole and voriconazole against clinical isolates of Candida spp. determined by disk diffusion testing in Turin, Italy. Antimicrob Agents Chemother. 2009; 53 (4): 1657-59. 
16. Pfaller MA, Diekema DJ, Gibbs DL, Newell VA, Ellis $D$, Tullio $V$, et al. Results from the ARTEMIS DISK global antifungal surveillance study, 1997 to 2007: a 10.5 year analysis of susceptibilities of Candida species to fluconazole and voriconazole as determined by CLSI standardized disk diffusion. J Clin Microbiol, 2010; 48 (4): 1366-77.

17. Swinne D, Watelle M, Flaes MV, Nolard N. In vitro activities of voriconazole (UK-109, 496), fluconazole, itraconazole and amphotericin B against 132 non-albicans bloodstream yeast isolates (CANARI study). Mycoses, 2004; 47: 177-83.

18. Gonzalez GM, Elizondo M, Ayala J. Trends in species distribution and susceptibility of bloodstream isolates of Candida collected in Monterrey, Mexico, to seven antifungal agents: results of a 3-year (2004 to 2007) surveillance study. J Clin Microbiol, 2008; 40(9): 2902-5.

19. Hajjeh RA, Sofair AN, Harrison LH, Lyon GM, Arthington-Skaggs BA, Mirza SA, et al. Incidence of bloodstream infections due to Candida species and in vitro susceptibilities of isolates collected from 1998 to 2000 in a population-based active surveillance program. J Clin Microbiol, 2004; 42 (4): 1519-27.

20. Takakura S, Fujihara N, Saito T, Kudo T, Linuma $Y$, Lchiyama S, et al. National surveillance of species distribution in blood isolates of Candida species in Japan and their susceptibility to six antifungal agents including voriconazole and micafungin. J Antimicrob Chemother, 2004; 53: 283-9.

21. Mokaddas EM, Al-Sweih NA, Khan ZU. Species distribution and antifungal susceptibility of Candida bloodstream isolates in Kuwait: a 10-year study. J Med Microbiol, 2007; 56: 255-9.
22. Samra Z, Yardeni M, Peled N, Bishara J. Species distribution and antifungal susceptibility of Candida bloodstream isolates in a tertiary medical in Israel. Eur J Clin Microbiol Infect Dis, 2005; 24; 592-5.

23. Martin D, Perasat F, Piens MA, Picot S. Candida species distribution in bloodstream cultures in Lyon, France, 1998-2001. Eur J Clin Microbiol Infect Dis, 2005; 24; 329-33.

24. Pfaller MA, Boyken L, Hollis RJ, Kroeger J, Messer SA, Tendolkar S, et al. Comparison of results of flukonazole and voriconazole disk diffusion testing for Candida spp. with results from a central reference laboratory in the ARTEMIS DISK global antifungal surveillance program. Diag Microbiol Infect Dis, 2009; 65: 27-34.

25. Doczi I, Dosa E, Hajdu E, Nagy E. Aetiology and antifungal susceptibility of yeast bloodstream infections in a Hungarian University hospital between 1996 and 2000. J Med Microbiol, 2002; 51: 677-81.

26. Lee MK, Kim HR, Kang JO, Kim MN, Kim EC, Kim JS, et al. Susceptibility and trailing growth of Candida albicans to fluconazole: results of a Korean multicenter study. Mycoses, 2007; 50: 148-9.

27. Mallie M, Bastide JM, Blancard A, Bonnin A, Bretagne $S$, Cambon M, et al. In vitro susceptibility testing of Candida and Aspergillus spp. to voriconazole and other antifungal agents using E-test $₫$ : results of a French multicentre study. Int J Antimicrob Ag, 2005; 25 (4): 321-28.

28. Messer SA, Jones RN, Fritsche TR. International surveillance of Candida spp. and Aspergillus spp: report from SENTRY antimicrobial surveillance program (2003). J Clin Microbiol, 2006; 44 (5): 1782-87.

29. Pfaller MA, Diekema DJ. Twelve years of fluconazole in clinical practice: global trends in species distribution and fluconazole susceptibility of bloodstream isolates of Candida group. Clin Microbiol Infect, 2004; 10 (1): 11-23. 
30. Cuenca-Estrella M, Rodriguez D, Almirante B, Morgan J, Planes AM, Almeda M, et al. In vitro susceptibilities of bloodstream isolates of Candida species to six antifungal agents: results from a population-based active surveillance programme, Barcelona, Spain, 2002-2003. J Antimicrob Chemother, 2005; 55: 194-99.
31. Kibbler CC, Seaton S, Barnes RA, Gransden WR, Holliman RE, Johnson EM, et al. Management and outcome of bloodstream infections due to Candida species in England and Wales. J Hospital Infect, 2003; 54: 18-24. 